\title{
Effect of ewe milk production on profitability of dryland lamb production systems
}

\author{
P.D. MUIR ${ }^{1}$, G.J. WALLACE ${ }^{1}$, D.G. McCALL ${ }^{2}$, and C.J. DODD ${ }^{3}$ \\ ${ }^{1}$ AgResearch Poukawa, PO Box 8144, Havelock North \\ ${ }^{2}$ AgResearch Ruakura, Private Bag 3123, Hamilton \\ ${ }^{3}$ Aorangi Rd, RD1, Hastings
}

\begin{abstract}
A farmlet study was carried out over 2 years to examine the role of milk production in dryland lamb production systems. Poll Dorset ewes (high milk producers) were mated with Romney rams and Romney ewes (average milk producers) were mated with Poll Dorset rams to produce lambs of a similar genotype. As well as two levels of milk production, two fecundity treatments were used and farmlets were replicated. Farmlets were 2.9 ha and stocked at a rate of 15 ewes/ha. Farmlets were managed to ensure similar pasture covers at the start of winter and at lambing. Poll Dorset ewes produced more milk and in both years their twin lambs had a small but significant advantage in lamb growth rate. This resulted in earlier drafting of lambs and the ability to obtain early season premiums. In the low fecundity farmlets, net financial returns for Romney and Poll Dorset ewes were $\$ 605 /$ ha and \$676/ha $(+12 \%)$ in Year 1 and \$709/ ha and $\$ 762 /$ ha $(+7 \%)$ in Year 2. For the high fecundity farmlets, financial returns for Romney and Poll Dorset ewes were \$637/ha and \$818/ha (+ $28 \%$ ) in Year 1 and \$866/ha and \$921/ha (+ 6\%) in Year 2. The greatest financial benefits to increased milk production were achieved in high fecundity ewes in Year 1 when feeding during lactation was less than optimal and this resulted in a significant effect on the rate at which twin lambs were drafted to achieve early season premiums. Lambs failing to reach minimum drafting weights were also penalised because of the prevailing drought conditions and low market prices for lighter lambs.
\end{abstract}

Keywords: breed, dryland, ewes, farming systems, fecundity, milk production, pre-weaning growth, profitability, sheep

\section{Introduction}

Early lamb production systems in dryland environments aim to produce marketable lambs ahead of the seasonal decline in the supply of high quality pasture. The early slaughter dates are also favoured because of premiums paid for early chilled lamb contracts. Recently, there has been renewed interest in the role of high milk producing dams with high levels of fecundity performing in a range of environments.

A farmlet study was undertaken over 2 years to determine the effects of milking ability on lamb production in a dryland environment. The goal of the farming systems studied was to maximise the production of 14 to $16 \mathrm{~kg} \mathrm{M}$ grade lamb carcasses before Christmas. Production data have been published previously (Muir et al. 1998) and this paper incorporates supplementary feed, slaughter and store value to give relative per hectare profitability of ewes with high and low milking ability.

\section{Methods}

Poll Dorset and Romney ewes were used to simulate high and average milk production. Poll Dorset ewes were mated to Romney rams and Romney ewes were mated to Poll Dorset rams to give lambs of a similar genotype. Treatments consisted of ewes at two levels of milk production and two levels of fecundity with each treatment replicated. Maiden two-tooth ewes were used in 1996 and remated in 1997.

Each farmlet comprised 2.9 ha and was stocked at 15 ewes/ha. A pool of "spare" animals was kept outside the farmlet to replace ewe and lamb deaths to maintain similar grazing pressures across treatments. Synchronised matings were achieved using progesteroneimpregnated controlled internal drug release devices (CIDR) in early March. Ewes remained on their farmlets until May when they were scanned before re-allocation to groups according to foetus number and liveweight.

Management decisions ensured that ewes had similar mating weights and that pasture cover levels on all farmlets were similar in early winter and at the start of lambing (Muir et al. 1998). The mean lambing dates were 5 August in 1996 (Year 1) and 8 August in 1997 (Year 2). Lambs were drafted off ewes at 2-weekly intervals from mid October to fixed liveweight criteria (34 $\mathrm{kg}$ for ram lambs and $32 \mathrm{~kg}$ for ewe lambs). When green leaf had disappeared from the pasture within the farmlets (determined visually), any remaining lambs 
were removed and treated as store lambs. In both years, this occurred in early December.

Ryegrass/mixed clover pastures were established over all the farmlets 12 months before commencement of the experiment. All farmlets were soil tested annually and fertiliser applied to ensure that nutrients were not limiting production. Pasture cover and ewe bodyweights were controlled across farmlets using supplementary feed at critical times to ensure results were interpretable (Sibbald $\&$ Maxwell 1990). The minimum target pasture covers were $1200 \mathrm{~kg} \mathrm{DM} / \mathrm{ha}$ on 1 May. Ewes were rotationally grazed through the winter with the aim of having minimum covers of $1200 \mathrm{~kg} \mathrm{DM} / \mathrm{ha}$ at lambing when ewes were set stocked. Surplus spring pasture was harvested as silage as commonly practised on farms. Supplements were introduced after weaning to restore bodyweight in high fecundity groups where necessary. Preventative treatments for internal and external parasites were administered and animals were vaccinated against common ewe and lamb diseases.

In each year, sub samples of ewes were machine milked using oxytocin following the method of McCance (1959) and Corbett (1968). In Year 1, 10 ewes rearing single lambs and 10 ewes rearing twin lambs were selected from each treatment (one replicate only) and milked 5 and 10 weeks after lambing. In Year 2, 10 ewes rearing single lambs and 10 ewes rearing twin lambs were selected from each treatment (both replicates) and milked at 3, 6, 9 and 12 weeks after lambing. Pasture mass was measured on each paddock monthly (see Muir et al. (1998) for more detailed methodology). Statistical levels of significance for dam breed, fecundity and ewe liveweight effects on lamb production were determined using least squares analysis. Drafting patterns were analysed by Chi-squared analysis. Milk production and fecundity effects on farmlet profitability per hectare were assessed by consideration of the slaughter returns (actual schedule plus premiums) and from store lambs $(\$ 1 / \mathrm{kg} \mathrm{LW}$ in Year 1 and $\$ 1.20 / \mathrm{kg}$ LW in Year 2). The amounts of supplements fed and/or made within the farmlets were also valued.

\section{Results}

Pasture growth rates were high in both years with an average pasture production of $12572 \mathrm{~kg} \mathrm{DM} / \mathrm{ha}$ in Year 1 and $12198 \mathrm{~kg} \mathrm{DM} / \mathrm{ha}$ in Year 2. Contrasting climatic conditions meant that seasonal feed supplies differed between years. Early onset of dry conditions in spring was followed by unseasonal rain after lambs had been slaughtered and drafted as stores. On the other hand, extremely dry conditions after the main lamb drafting period resulted in very low summer pasture covers in Year 2 (see Muir et al. 1998).

Ewe bodyweights were high for New Zealand conditions with mean premating weights for Poll Dorsets and Romneys of $69.0 \mathrm{~kg}$ and $62.8 \mathrm{~kg}$ in Year 1 as twotooths and $83.5 \mathrm{~kg}$ and $76.3 \mathrm{~kg}$ in Year 2 (Muir et al. 1998). High fecundity ewes were lighter at weaning than ewes rearing singles and had to be offered greater amounts of supplements post weaning to ensure ewe mating weights were achieved.

Ewe milk production was highly variable within a breed. Differences in milk production between breeds were greatest in ewes rearing twins particularly in late lactation when Poll Dorset ewes produced up to $170 \%$ more milk than Romney ewes (Table 1). Lambs reared by Poll Dorset ewes grew faster than those reared by Romney ewes, particularly in the high fecundity groups $(\mathrm{P}<0.001$, Table 2$)$. Lambs in the low fecundity groups grew significantly faster than those in high fecundity groups in both Year $1(\mathrm{P}<0.001)$ and Year $2(\mathrm{P}<0.05)$.

Table 1 Milk production means (litres/ewe/day) of low and high fecundity Dorset and Romney ewes.

\begin{tabular}{|c|c|c|c|c|c|c|c|c|}
\hline & \multicolumn{4}{|c|}{ Low fecundity } & \multicolumn{4}{|c|}{ High fecundity } \\
\hline $\begin{array}{l}\text { Year } 1 \\
\text { Week of lactation }\end{array}$ & & & & & & & & 0 \\
\hline $\begin{array}{l}\text { Poll Dorset } \\
\text { Romney } \\
\text { Significance }\end{array}$ & & & & & & $\begin{array}{l}99 \\
59 \\
*\end{array}$ & & $\begin{array}{l}02 \\
75 \\
*\end{array}$ \\
\hline $\begin{array}{l}\text { Year } 2 \\
\text { Week of lactation }\end{array}$ & 3 & 6 & 9 & 12 & 3 & 6 & 9 & 12 \\
\hline $\begin{array}{l}\text { Poll Dorset } \\
\text { Romney } \\
\text { Significance }\end{array}$ & $\begin{array}{c}2.12 \\
1.97 \\
\mathrm{~ns}\end{array}$ & $\begin{array}{c}2.21 \\
1.68 \\
\mathrm{~ns}\end{array}$ & $\begin{array}{c}1.89 \\
1.18 \\
\star * \star\end{array}$ & $\begin{array}{c}1.47 \\
0.71 \\
* * *\end{array}$ & $\begin{array}{c}2.85 \\
2.65 \\
\text { ns }\end{array}$ & $\begin{array}{l}2.70 \\
2.04 \\
*\end{array}$ & $\begin{array}{l}2.52 \\
1.73 \\
* * *\end{array}$ & $\begin{array}{l}1.84 \\
0.88 \\
* * *\end{array}$ \\
\hline
\end{tabular}

a Significance of the dam breed effects; $n s=P>0.05 ;{ }^{*}=P<0.05 ;{ }^{* *}=P<0.01$; $* * *=P<0.001$

Drafting patterns were significantly different between dam breeds in the high fecundity farmlets (Year 1: $\mathrm{P}<0.001$; Year 2: $\mathrm{P}<0.05$ ) but were non-significant in low fecundity farmlets (Years 1 and $2: \mathrm{P}>0.05$ ).

There were no significant differences between dam breeds (within a fecundity group) in average liveweights of lambs drafted for slaughter or as stores (Table 3). Average slaughter liveweights tended to be higher in the low fecundity groups, reflecting a number of lambs over the drafting liveweights when drafting commenced and the higher growth rates of lambs reared by low fecundity ewes when drafted at fixed intervals.

Although there were no significant differences in liveweight immediately before slaughter, lamb carcass weights differed significantly between dam breeds for 
Table 2 Mean numbers of lambs reared per ewe, lamb liveweight gains to weaning ( \pm SEM) and the percentage of lambs drafted by 2 December from Poll Dorset and Romney ewes run in low and high fecundity farmlets

\begin{tabular}{|c|c|c|c|c|c|c|}
\hline & \multicolumn{3}{|c|}{ 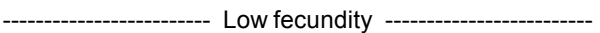 } & \multicolumn{3}{|c|}{ - } \\
\hline & $\begin{array}{l}\text { Lambs } \\
\text { reared/ewe }\end{array}$ & $\begin{array}{l}\text { Liveweight gain } \\
\text { (g/day) }\end{array}$ & $\begin{array}{c}\% \text { Lambs drafted } \\
\text { by } 2 \mathrm{Dec}\end{array}$ & $\begin{array}{l}\text { Lambs } \\
\text { reared/ewe }\end{array}$ & $\begin{array}{l}\text { Liveweight gain } \\
\text { (g/day) }\end{array}$ & $\begin{array}{c}\% \text { Lambs drafted } \\
\text { by } 2 \text { Dec }\end{array}$ \\
\hline \multicolumn{7}{|l|}{ Year 1} \\
\hline Poll Dorset & 1.09 & $338 \pm 5.3$ & 93 & 1.92 & $280 \pm 4.0$ & 56 \\
\hline $\begin{array}{l}\text { Romney } \\
\text { Significance }^{a}\end{array}$ & 1.04 & $\underset{*}{328} \pm 5.3$ & 95 & 1.72 & $\underset{* \star \star}{244 \pm 4.4}$ & 23 \\
\hline \multicolumn{7}{|l|}{ Year 2} \\
\hline Poll Dorset & 1.32 & $317 \pm 4.3$ & 90 & 1.93 & $307 \pm 3.3$ & 85 \\
\hline Romney & 1.26 & $300 \pm 4.2$ & 93 & 1.77 & $283 \pm 3.5$ & 81 \\
\hline Significance ${ }^{a}$ & & ns & & & 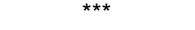 & \\
\hline
\end{tabular}

Table 3 Least squares means for liveweights of lambs drafted for slaughter ( \pm SEM), carcass weights and GR (fat depth) of lambs slaughtered $( \pm$ SEM) and liveweights of store lambs from Poll Dorset and Romney ewes run in low and high fecundity farmlets (numbers of lambs are in parentheses).

\begin{tabular}{|c|c|c|c|c|c|c|c|c|}
\hline & $\begin{array}{c}\text { Slaughter } \\
\text { liveweight }(\mathrm{kg})\end{array}$ & $\begin{array}{l}\text { Carcass } \\
\text { weight }(\mathrm{kg})\end{array}$ & $\begin{array}{l}\text { fecundity } \\
\text { GR (mm) }\end{array}$ & Store LW (kg) & $\begin{array}{c}\text { Slaughter } \\
\text { liveweight }(\mathrm{kg})\end{array}$ & $\begin{array}{c}\text { Carcass } \\
\text { weight }(\mathrm{kg})\end{array}$ & $\begin{array}{l}\text { fecundity ----- } \\
\text { GR (mm) }\end{array}$ & Store LW $(\mathrm{kg})$ \\
\hline \multicolumn{9}{|l|}{ Year 1} \\
\hline Poll Dorset & $35.8 \pm 0.42(74)$ & $17.0 \pm 0.15$ & $11.2 \pm 0.42(74)$ & $31.4 \pm 1.14(7)$ & $33.9 \pm 0.25(77)$ & $15.4 \pm 0.15$ & $8.3 \pm 0.41(77)$ & $27.8 \pm 0.41$ \\
\hline Romney & $35.0 \pm 0.27(69)$ & $16.2 \pm 0.16$ & $8.6 \pm 0.44(69)$ & $31.9 \pm 1.35(5)$ & $33.4 \pm 0.40(30)$ & $14.5 \pm 0.24$ & $6.1 \pm 0.66(30)$ & $27.2 \pm 0.30(99)$ \\
\hline Significance $^{a}$ & ns & ** & $* * *$ & ns & ns & * & * & ns \\
\hline \multicolumn{9}{|l|}{ Year 2} \\
\hline Poll Dorset & $35.1 \pm 0.21(93)$ & $16.0 \pm 0.14$ & $9.8 \pm 0.33(93)$ & $29.8 \pm 1.26(5)$ & $35.0 \pm 0.17(145)$ & $15.4 \pm 0.11$ & $8.5 \pm 0.26(145)$ & $29.5 \pm 0.68$ (17) \\
\hline Romney & $35.0 \pm 0.21$ & $15.4 \pm 0.13$ & $7.7 \pm 0.32(97)$ & $31.9 \pm 1.40(4)$ & $34.7 \pm 0.18$ & $14.8 \pm 0.11$ & $6.3 \pm 0.27(133)$ & $31.0 \pm 0.78(13)$ \\
\hline Significance $^{a}$ & ns & * & $* * *$ & $\mathrm{~ns}$ & ns & $* * *$ & $* * *$ & ns \\
\hline
\end{tabular}

Table 4 Lamb returns and supplementary feed value per hectare for lamb production systems using Poll Dorset and Romney ewes run in low and high fecundity farmlets.

\begin{tabular}{|c|c|c|c|c|c|c|c|c|c|c|c|c|}
\hline & \multicolumn{6}{|c|}{ 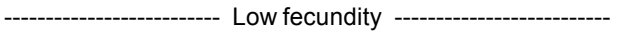 } & \multicolumn{6}{|c|}{ 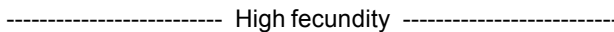 } \\
\hline & $\begin{array}{c}\text { Slaughter } \\
\text { lambs } \\
\$ / h a\end{array}$ & $\begin{array}{c}\text { Store } \\
\text { lambs } \\
\$ / h a\end{array}$ & $\begin{array}{c}\text { Ave } \\
\text { lamb } \\
\text { value }(\$)\end{array}$ & $\begin{array}{l}\text { Suppl } \\
\text { made } \\
\$ / h^{*}\end{array}$ & $\begin{array}{l}\text { Suppl } \\
\text { fed } \\
\$ / h^{*}\end{array}$ & $\begin{array}{c}\text { Net } \\
\text { surplus } \\
\$ / \text { ha }\end{array}$ & $\begin{array}{c}\text { Slaughter } \\
\text { lambs } \\
\$ / h a\end{array}$ & $\begin{array}{c}\text { Store } \\
\text { lambs } \\
\$ / \text { ha }\end{array}$ & $\begin{array}{c}\text { Ave } \\
\text { lamb } \\
\text { value (\$) }\end{array}$ & $\begin{array}{l}\text { Suppl } \\
\text { made } \\
\$ / h^{*}\end{array}$ & $\begin{array}{l}\text { Suppl } \\
\text { fed } \\
\text { \$/ha* }\end{array}$ & $\begin{array}{c}\text { Net } \\
\text { surplus } \\
\$ / h a\end{array}$ \\
\hline \multicolumn{13}{|l|}{ Year 1} \\
\hline Poll Dorset & $\$ 624$ & $\$ 27$ & 47.14 & $\$ 26$ & - & $\$ 676$ & $\$ 609$ & $\$ 293$ & 37.35 & - & $\$ 84$ & $\$ 818$ \\
\hline Romney & $\$ 570$ & $\$ 21$ & 46.35 & $\$ 14$ & - & $\$ 605$ & $\$ 217$ & $\$ 477$ & 30.74 & - & $\$ 57$ & $\$ 637$ \\
\hline \multicolumn{13}{|l|}{ Year 2} \\
\hline Poll Dorset & $\$ 708$ & $\$ 25$ & 40.63 & $\$ 33$ & $\$ 4$ & $\$ 762$ & $\$ 982$ & $\$ 83$ & 38.31 & - & $\$ 144$ & $\$ 921$ \\
\hline Romney & $\$ 703$ & $\$ 13$ & 39.09 & $\$ 9$ & $\$ 17$ & $\$ 709$ & $\$ 868$ & $\$ 72$ & 36.36 & - & $\$ 74$ & $\$ 866$ \\
\hline
\end{tabular}

* Supplements made and fed have all been calculated and valued as silage with a M/D of 10 MJME and a value of $14 \mathrm{c} / \mathrm{kg}$ DM.

both fecundity groups in both years. These differences in carcass weight reflected differences in dressing out percentages. Similarly, there were significant dam effects on carcass fatness. Lambs reared by Poll Dorset ewes were heavier and fatter than lambs reared by Romney ewes.

Added supplementary feed costs were associated with high fecundity farmlets; $\$ 57 /$ ha for the high fecundity Romneys and \$84/ha for the high fecundity
Poll Dorsets in Year 1 (Table 4). In Year 2 these costs increased to $\$ 74 / \mathrm{ha}$ and $\$ 144 / \mathrm{ha}$, respectively, when very dry summer conditions were experienced. Feeding out to high fecundity ewes post weaning assisted in ensuring that satisfactory mating weights and animal performance were achieved subsequently. No supplements were fed to the low fecundity groups in Year 1 and minimal quantities were required in Year 2 (Table 4). 
In the low fecundity groups, increased milk production improved per hectare profitability by $12 \%$ and $7 \%$ in Year 1 and Year 2, respectively. In the high fecundity groups, increased milk production increased profitability by $28 \%$ in Year 1 and $6 \%$ in Year 2. However in all treatments and in both years, Poll Dorset ewes reared slightly more lambs than Romney ewes (see Table 2). This would have improved the per hectare returns for the high milk producing ewes. When average lamb returns were examined (Table 4), the main benefits of milking ability occurred in high fecundity ewes, with average lamb values being $21 \%$ higher in Year 1 and $5 \%$ higher in Year 2. In low fecundity ewes, average lamb returns in the Poll Dorset farmlets were $1 \%$ and $3 \%$ higher in Year 1 and Year 2, respectively. Thus the main effect of milking ability occurred in high fecundity treatments, particularly in Year 1 . This coincided with reduced pasture covers in late lactation and lower growth rates in lambs, particularly those reared by high fecundity Romney ewes.

\section{Discussion}

Increased milking ability did not confer any substantial lamb growth rate advantage at low fecundity levels and this suggests that single lambs were unable to harvest the extra milk produced by well fed Poll Dorset ewes. However the combined benefits of the slightly greater value of both the slaughter and store lambs and the additional dry matter conserved on the low fecundity farmlets running Poll Dorset ewes contributed to improved profitability.

The higher milking ability of Poll Dorset ewes meant that twin lambs had a growth rate advantage which translated to earlier drafting and a substantial economic gain in Year 1. The better pasture cover and/ or quality in Year 2 meant that lambs in the high fecundity Romney groups were probably able to substitute sufficient pasture for a declining milk supply and to maintain relatively high growth rates and economic performance. This is consistent with the suggestion of Geenty (1979) that the supply of good quality pasture during lactation can even out the influence that differences in milk supply may have on lamb growth rates.

This study also highlighted the ability of higher milk producing ewes to produce heavier carcasses from lambs drafted to the same target liveweight. It also demonstrated the extent to which lambs reared by ewes with higher milking ability are more likely to be overfat when drafted at a set liveweight, particularly those reared as singles. Careful drafting and review of liveweight criteria are very important for lambs from high milk producing dams to ensure that these lambs are slaughtered at optimal GR fat depths to maximise carcass value.

These results suggest that the benefits of improved ewe milking ability will only be achieved in high performance flocks (i.e., those with a high proportion of twins). High milk producing ewes may enable more lambs to be finished under adverse conditions thus reducing the need to carry as many store lambs into dry summers. This will also assist in the sale of more lambs pre-Christmas when schedule values are often higher. For example, over the 2 years of this study a $16 \mathrm{~kg} \mathrm{PM}$ grade lamb was worth $\$ 9.14$ more if slaughtered in mid October rather than early December.

In this study, it was apparent that high milk producing ewes rearing twins were more likely to be subject to greater body weight loss during the lactation period. Separation of animals that have undergone excessive weight loss may be advantageous to help ensure they are fed at a higher intake after weaning to reach target mating weights and repeat their performance. Farmers targeting high performance need to be able to implement more intensive management practices in seasons which require it.

This study has focused on milk production, consequently the difference in average fleece weights of the Poll Dorset $(3.09 \mathrm{~kg})$ and Romney ewes $(5.17 \mathrm{~kg})$ has been ignored. However, at a value of $\$ 2.78 / \mathrm{kg}$ greasy and a shearing cost of $\$ 1.50$ /ewe, net wool returns for Romney ewes averaged $\$ 193 / \mathrm{ha}$. It is interesting to note that if these wool values had been produced by the Poll Dorset ewes, then average net returns for the high fecundity, high milk farmlets would have increased to \$1062/ha.

\section{ACKNOWLEDGEMENTS}

The authors gratefully acknowledge the assistance of Noel Smith and Clare Fugle with data collection. This study was undertaken through the Sheep Forage Systems programme with funding from the Foundation for Research, Science and Technology (Contract C10 623).

\section{REFERENCES}

Corbett J.L. 1968. Variation in the yield and composition of milk of grazing Merino ewes. Australian journal of agricultural research 19: 283-294.

Geenty, K.G. 1979. Lactation performance, growth, and carcass composition of sheep. 1. Milk production, milk composition, and liveweights of Romney, Corriedale, Dorset, Romney X Dorset, and Dorset $\mathrm{X}$ Romney ewes in relation to the growth of their lambs. New Zealand journal of agricultural research 22: 241-250. 
McCance, I. 1959. The determination of milk yield in the Merino ewe. Australian journal of agricultural research 19: 283-294.

Muir, P.D.; Wallace, G.J.; McCall, D.G.; Dodd, C.J. 1998. The role of milk production in dryland lamb production systems. Proceedings of the New Zealand Society of Animal Production 58: 170-174.

Sibbald, A.R.; Maxwell, T.J. 1990. Contrasting approaches to systems research for sheep production in the hills and uplands of the United Kingdom. pp. 1-11. In: Commission of the European Communities; Proceedings of Livestock Systems Symposium, Toulouse, France. 
